\title{
Effects of Sowing Time on the Growth, Development and Productivity of Sweet Sorghum
}

\author{
Hoang Thi Bich Thao", Tran Van Dien"1, Tran Dang Xuan ${ }^{2 *}$ \\ ${ }^{1}$ Thai Nguyen University of Agriculture and Forestry, Thai Nguyen City, Vietnam \\ ${ }^{2}$ Graduate School for International Development and Cooperation (IDEC), Hiroshima University, Hiroshima \\ Prefecture, Japan \\ Email: "tdxuan@hiroshima-u.ac.jp
}

Received 1 May 2015; accepted 21 November 2015; published 24 November 2015

Copyright (C) 2015 by authors and Scientific Research Publishing Inc.

This work is licensed under the Creative Commons Attribution International License (CC BY).

http://creativecommons.org/licenses/by/4.0/

(c) (i) Open Access

\section{Abstract}

The experiments were conducted to determine suitable sowing time in order to achieve high plant biomass and sugar content of sweet sorghum for bioethanol manufacture. The results showed that germination rate reached $>80 \%$ in all trial times $(p>0.05)$. The growth and development speed of sweet sorghum reduced when seeds were sowed in August and was significantly different from other sowing times $(p<0.05)$. Sowing from March to June obtained the highest plant height during all growth and development stages. Lodging and diseases observed in all periods of sowing, and planting began in July and August had lower percentage. In contrast, the productivity of fresh weight (1310.4 g/whole plant), sugar content (14.9\% Brix), biomass yield (122.4 tons/ha) and theoretical converted ethanol yield ( 5 tons/ha) were the highest when sweet sorghum planted from March to June. It was observed that sowing sweet sorghum in four periods of month from March to June had the desirable biomass for bioethanol production.

\section{Keywords}

Bioethanol, Biomass, Sowing, Sugar Content, Sweet Sorghum

\section{Introduction}

Renewable energy resources have been intentionally pursuing as the current sources of energy that have gradually exhausted [1] [2]. Bioethanol is regarded as the potentially replaceable source and is internationally studied

\footnotetext{
${ }^{*}$ Corresponding author.
}

How to cite this paper: Thao, H.T.B., Van Dien, T. and Xuan, T.D. (2015) Effects of Sowing Time on the Growth, Development and Productivity of Sweet Sorghum. Journal of Sustainable Bioenergy Systems, 5, 127-135. 
in the majority of institutions [1] [3]. Bioethanol could be collected from the microbial metabolism or plant biomass production [2] [4]-[6]. In 2007, Vietnamese government has suggested the promotion for bioethanol production from sugarcane and cassava biomass grown in many appropriate areas [7]. Nevertheless, those crops have respectively been feedstock for sugar manufacture and consumption, and they are usually affected by trading cost. Consequently, it is imperative than other raw replaceable materials have been employed to produce biofuel.

Currently, sweet sorghum (Sorghum bicolor (L.) Moench) has been one of the most prioritycrops being considered in producing bioethanol in many countries [3] [5] [6] [8] [9]. The stalk of sweet sorghum contains 75\% extract mostly comparable to that of sugarcane, and such a crop is enable to be grown in poor soil areas, and is highly resistant to insects and microbiological diseases [2] [3] [6] [10]-[13]. In addition, sweet sorghum is not going to affect the food security since it is not the staple food for human consumption. Therefore, sweet sorghum is greatly suitable to develop for bioethanol manufacture objective in Vietnam.

Vietnam climate is more likely to be complicated dramatically fluctuation of temperature, from $3^{\circ} \mathrm{C}$ to $5^{\circ} \mathrm{C}$ in the North and even to 10 degree Celsius in the South [14]. Therefore, the Northern region seems to be more appropriate for cultivating sweet sorghum, and Thai Nguyen province is firstly chosen for trial cropping because of its salubrious climate. An instance of this is the range of temperature which varies from $18^{\circ} \mathrm{C}$ to $20^{\circ} \mathrm{C}$, and the rainfall in this region changes approximately from 2000 to $2500 \mathrm{~mm}$ annually [15]. Briefly, Thai Nguyen is actually encouraging for sweet sorghum planting with highly expected productivity. However, the adaptation of sorghum at each growth stage heavily depends on the environmental conditions. Despite marginal change in temperature and rain density, plant in vulnerable stage is easily affected. It is necessary to evaluate the effects of sowing time from March to August on the germination rate, growth, development, and especially the quality of the desirable product as sugar content.

\section{Materials and Methods}

\subsection{Sweet Sorghum Cultivars}

The sweet sorghum was hybrid cultivar obtained from Japan. Experiments were conducted in Thai Nguyen University of Agriculture and Forestry.

\subsection{Field Experiment}

Six treatments of sowing time were randomly distributed in block with 3 replications for each treatment. The area of each plot was $4.55 \mathrm{~m} \times 5 \mathrm{~m}\left(22.75 \mathrm{~m}^{2}\right)$, and the distance of two plots was $1 \mathrm{~m}$. Each row and seed had a space of $0.6 \mathrm{~m}$ and $0.15 \mathrm{~m}$, respectively.

Fertilizers were totally applied during the crop with 10 tons of compost per ha, 3 tons of microbial fertilizer per ha, and the ratio of Nitrogen (N), Phosphorus (P) and Potassium (K) was $300 \mathrm{~N}+96 \mathrm{P}_{2} \mathrm{O}_{5}+134 \mathrm{~K}_{2} \mathrm{O}$ per ha, respectively.

\subsection{Effects of Sowing Time on the Growth and the Development of Sweet Sorghum}

The seeds were sowed in six different months consisting of March, April, May, June, July and August in the same year as treatments.

\section{Evaluated criteria:}

Germination rate: The germination rate was calculated as the ratio of the percentage of germinated seeds (a coletile comes out from the soil) and the total sowed seeds.

Time of growth: Days after sowing were recorded during the growth and development of sweet sorghum. There were six periods including heading, milk ripe, dough-ripe, complete ripe and harvest.

Heading day: Over $50 \%$ of flowering plants about one-third of the main stem.

Milk ripe day: Over $50 \%$ of plants with milk ripe seeds.

Dough-ripe day: Over $50 \%$ of plants with dough-ripe seeds.

Complete ripe day: The day over $75 \%$ of plants with a dark-pot at seed bottom.

Harvest day: When the Brix degree reached the highest value (commonly between milk ripe and dough-ripe stage).

Growth speed: Randomly took 10 plants/row for measuring the plant height at the $30^{\text {th }}, 60^{\text {th }}, 90^{\text {th }}, 120^{\text {th }}$ day and harvest days after sowing. If the plants did not flower, the plant height would be recorded from the land to 
the tip of the highest leaf. After flowering, it was measured from the land to the tip of the flower.

Number of leaves: Counted the number of leaves each plant at $30^{\text {th }}, 60^{\text {th }}, 90^{\text {th }}, 120^{\text {th }}$ day and heading days after sowing.

Resistant level against pests and diseases: Stem borer: Observed and recorded the presence of stem borer. Counted the number of infected plants, and then calculated the damage percentage. Finally, scored the resistant level.

Score 0: Very good (None infected plant).

Score 1: Good (Lower 5\% of infected plants).

Score 2: Slightly good (From $5 \%$ to $15 \%$ of infected plants).

Score 3: Moderate (From 15\% to 25\% of infected plants).

Score 4: Susceptible (From 25\% to 35\% of infected plants).

Score 5: Very susceptible (Higher 35\% of infected plants).

Damage percentage $(\%)=$ Total damaged plants/Total plants $\times 100$.

Stem rot and root rot by microorganisms: Observed and recorded the presence of diseases. Counted the number of infected plants, and then calculated the damage percentage. Eventually, scored the susceptible level.

Score 0: None infected plant.

Score 1: Very slightly susceptible (From $1 \%$ to $10 \%$ of infected plants).

Score 2: Slightly susceptible (From $1 \%$ to $10 \%$ of infected plants).

Score 3: Moderate susceptible (From 26\% to 50\% of infected plants).

Score 4: Highly susceptible (From $51 \%$ to $75 \%$ of infected plants).

Score 5: Severely susceptible (Higher $75 \%$ of infected plants).

Lodging resistant level: Lodging plant was counted when the stem bended and created an angle of $30^{\circ}$ or more with the vertical stance.

Lodging percentage $(\%)=$ Total lodged plants/Total plants $\times 100$.

The lodging resistant level was scored.

Score 1: Very good (From $0 \%$ to $15 \%$ of lodged plants).

Score 2: Good (From 16\% to 30\% of lodged plants).

Score 3: Moderate (From $31 \%$ to $45 \%$ of lodged plants).

Score 4: Bad (Higher 45\% of lodged plants).

\subsection{Effects of Sowing Times on the Yield of Sweet Sorghum}

Stem diameter: Ten plants were chosen for measuring their diameters at the biggest position of the stem (commonly about 20 - $30 \mathrm{~cm}$ from land on harvest day).

Fresh weight (g/whole plant): Weighed all leaves and stem of each plant of ten plants and expressed as average.

Fresh weight of stem (g/stem): Weighed the stem of each plant (without leaves and flowers) of ten plants and expressed as average.

Biomass yield (tons/ha): Each trial land was divided into 2 parts, one was used for measuring stem yield and the other was preserved for calculating the biomass yield, in which:

Biomass yield (tons/ha $)=\frac{\left[\left(\text { Weight of whole plant in } \frac{1}{2} \text { trial land }(\mathrm{kg}) / \text { Area of } \frac{1}{2} \text { trial land }\left(\mathrm{m}^{2}\right)\right) \times 10,000\right]}{1000}$

Biomass yield (tons/ha $)=\frac{\left[\left(\text { Weight of stem plant in } \frac{1}{2} \text { trial land }(\mathrm{kg}) / \text { Area of } \frac{1}{2} \text { trial land }\left(\mathrm{m}^{2}\right)\right) \times 10,000\right]}{1000}$

Quality: The quality of sorghum was regarded as the sugar content or Brix level (\%) of stem juice that was squeezed from the stem and measured by a Brix meter (Atago, Japan) at four periods of seed ripeness (heading, milk ripe, dough-ripe, and complete ripe).

The ethanol yield was theoretically converted from the Brix value, which equaled Brix value $(\%) \times 6.5$ (converting index) $\times 0.85$ (producing index) $\times$ stem yield (tons/ha). 


\subsection{Statistical Analysis}

The recorded data were expressed as means of repeated measurements and statistically analyzed using one-way Anova and LSD test with 95\% confident level by SAS software.

\section{Results and Discussion}

\subsection{Climate in Thai Nguyen}

Annually, the temperature in this province ranges from $15.6^{\circ} \mathrm{C}$ to $28.9^{\circ} \mathrm{C}$, and the average is $23.4^{\circ} \mathrm{C}$. The highest temperature falls in June when the summer almost went by, and the lowest is January. In addition, the average amount of rainfall is approximately $2000 \mathrm{~mm}$ with the highest precipitation about $420 \mathrm{~mm}$ (Figure 1). Therefore the climate in Thai Nguyen is evaluated as mild and warm temperature [15].

\subsection{Germination Rate and Duration of Growth and Development}

Germination stage plays a crucial role in all stages of growth and development of plants as well as potential productivity [16]. Sweet sorghum seeds started germinating at $10^{\circ} \mathrm{C}$ and higher and even germinated faster at $15^{\circ} \mathrm{C}$ and upper. However, under the former condition, plants are more vulnerable to disease because of feeble stress tolerance [9]. Proximately, the germination process took place of a fortnight at the temperature of $15^{\circ} \mathrm{C}$ with $80 \%$ germinated seeds [17]. The germination percentage in this study was expressed in Table 1 . As can be seen from the table, the germination rates from March to August experienced an insignificant difference (95\% confidential level)with figures ranging from $84 \%$ - 90.2\%.These germination rates reached the national level of seed standard, which is comparable or higher $85 \%$.

The growth and development of sweet sorghum was presented in Table 1. Plants had the longest periods from sowing in March to July with about 118 to $121 \mathrm{~d}(\mathrm{p}>0.05)$. In August, the time was shorter two days, and it was significantly different to other times $(\mathrm{p}<0.05)$ due to gradually decreased temperature. The planting seasons did not affect the germination while duration of growth and development of sweet sorghum was shorter when seeds were sown in August. Actually, the long photoperiod is favorable for flora grow and development, particularly longer than $12 \mathrm{~h}$. In the case of sweet sorghum, about $10 \mathrm{~h}$ of daily light long is the best appropriate condition [17]. It is believed that daily photoperiod in August was shorter, and consequently caused faster in growth and development of sweet sorghum. Notwithstanding that plant height is not considered as the main contributor to

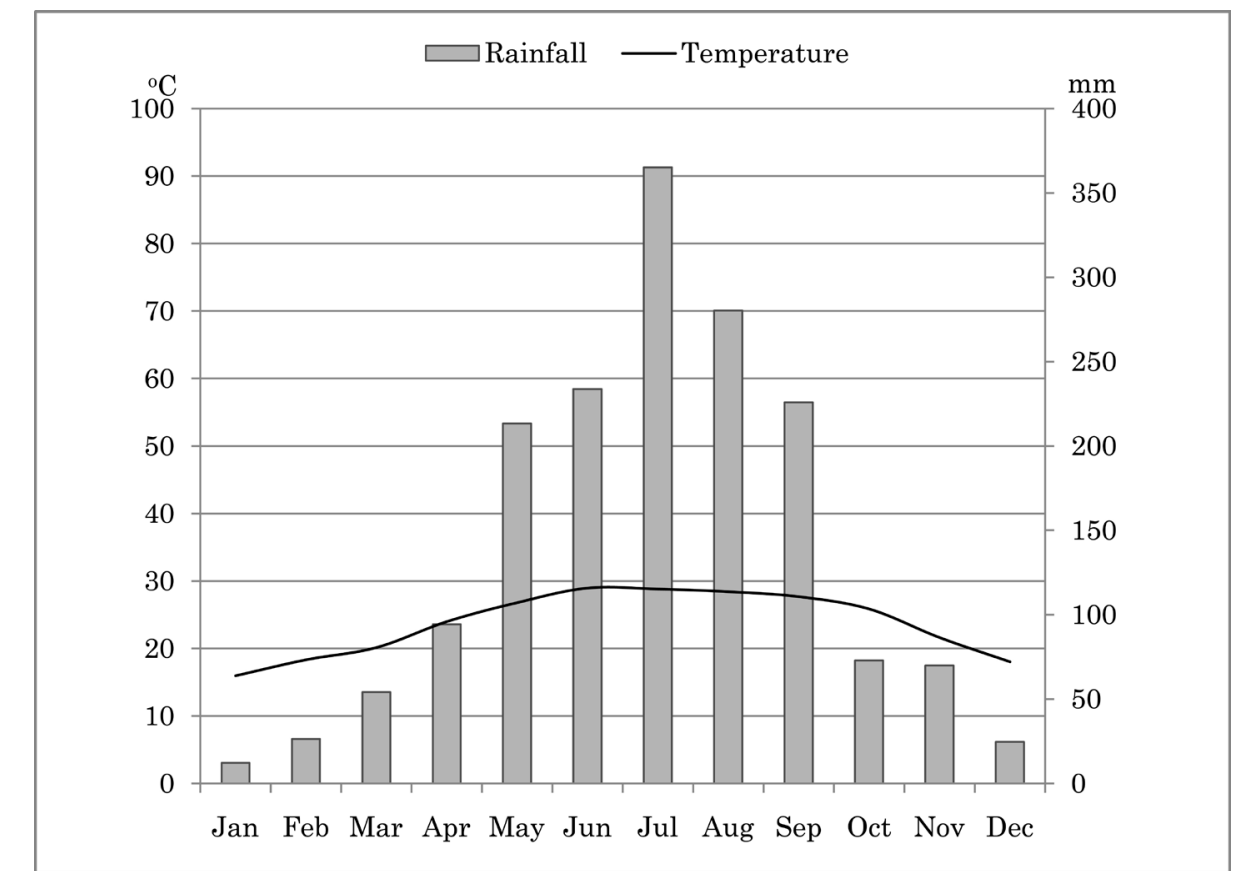

Figure 1. Annual temperature and rainfall in Thai Nguyen [15]. 
Table 1. Effects of sowing times to germination rate (\%) and the growth and development of sweet sorghum (d).

\begin{tabular}{|c|c|c|c|c|c|}
\hline Sowingtimes & Heading & Milkripe & Dough-ripe (Harvest) & Complete ripe & Germinationrate (\%) \\
\hline Mar. 25 & $83.3 \mathrm{bc}$ & $98.3 \mathrm{ab}$ & $108.0 \mathrm{a}$ & $121.0 \mathrm{a}$ & $85.2 \mathrm{a}$ \\
\hline April. 15 & $84.7 \mathrm{a}$ & 99.3 a & 108.3 a & $120.7 \mathrm{ab}$ & $87.3 \mathrm{a}$ \\
\hline May 15 & $84.0 \mathrm{ab}$ & $98.0 \mathrm{ab}$ & $107.3 \mathrm{a}$ & $119.3 \mathrm{ab}$ & $90.2 \mathrm{a}$ \\
\hline Jun. 15 & $83.0 \mathrm{bc}$ & $97.3 \mathrm{ab}$ & $105.7 \mathrm{~b}$ & $119.0 \mathrm{ab}$ & 86.4 a \\
\hline Jul. 15 & $82.3 \mathrm{c}$ & $97.0 \mathrm{bc}$ & $104.7 \mathrm{~b}$ & $118.7 \mathrm{~b}$ & $84.0 \mathrm{a}$ \\
\hline Aug. 15 & $79.3 \mathrm{~d}$ & $95.0 \mathrm{c}$ & $103.0 \mathrm{c}$ & $116.0 \mathrm{c}$ & $84.0 \mathrm{a}$ \\
\hline $\mathrm{P}$ & $<0.01$ & 0.02 & $<0.01$ & $<0.01$ & 0.29 \\
\hline
\end{tabular}

Means with different following letters in the same column are significantly different at 95\% confidential level.

ethanol production, it is an essential factor reflecting quite reasonably the growth, development and biomass of plants. Plant height is controlled by a combination of genes and environmental factors including water, temperature, sunlight, and humidity.

The influence of sowing time on plant height of sweet sorghum was showed in Table 2. In general, the sowing time from March to June witnessed the insignificant difference in plant height of sorghum after 120 days of growing ( $>$ > 0.05). In particular, after 30 days of sowing, the plant height was $84.7 \mathrm{~cm}$ when sorghums were sown in June, followed by in May, April and March with $78.8 \mathrm{~cm}, 73.1 \mathrm{~cm}$ and $68.8 \mathrm{~cm}$, respectively. This figure was the lowest with $43.3 \mathrm{~cm}$ in August treatment $(\mathrm{p}<0.05)$. Similarly, after 90 days of sowing, the plant height was unchanged because the productive stage occurs these days [17].

The plants reached their maximum height on day $90^{\text {th }}$ after sowing, and it was stable until harvesting. The four planting times consisting of March, April, May and June experienced an inconsiderable difference in plant height despite the fact that sweet sorghums sown in July and August had substantially lower height which were 378.1 and $241.3 \mathrm{~cm}$ in harvesting, respectively $(\mathrm{p}<0.01)$. The average plant height of sweet sorghum was approximately $320 \mathrm{~cm}$ [18], but because the sweet sorghum in this research was the hybrid, the height of plant was dramatically higher. In addition, this figure was extremely greater than that of four genotypes of sweet sorghum planted in Hyderabad, India—a semiarid tropical climate, which was $300 \mathrm{~cm}$ in average [6].

It can be concluded that sowing time greatly affected the plant height, and which led to the change in the biomass of sweet sorghum. The appropriate sowing time for plant growth and development was in summer (from March to June).

\subsection{Lodging Rate}

Lodging in sweet sorghum extremely contributes in losing sugar content after harvest due to decrease of photosynthesis effectiveness. Moreover, in the case of early stage lodging such as booting or heading stages, the plant biomass probably drops and accordingly reduces the ultimate yield.

As can be observed in the Table 3, the lodging percentage slightly increased from March to April. The lodging level was much greater in May, at 20.3\%. To put it simply, sowing sorghum in May highly caused lodging of plant because this period had heavy rain and storm. The crop was not affected in term of lodging percentage, with only 5.9\% and 3.9\% when sorghum was sowed in July and August, respectively. However, planting in these two months was not good for young trees because of heavy and endless rain, but the crop could victoriously evade from storm at the harvest time. In point of fact, the lodging rates in all treatments were acceptable and met good and very good resistant level.

\subsection{Pests and Diseases Infection}

Environmental factors greatly contribute to the healthy growth and development of plants, especially they affect the physiochemical and metabolic activities [9]. Among a wide range of serious diseases, stem borer and stem rot diseases which are caused by stem borer and bacteria respectively, are the most primary enemies of sorghum, severely damaging the biomass yield and sugar amount of this kind of sweet sorghum plants [17].

Sorghum has a high ability to resistant to the damage from pests and diseases [1] [11] [18]-[20]. The affected percentage from stem borer and diseases from microorganisms heavily depended on the environmental conditions which inextricably linked to the planting times [9] [17] showed in Table 4. The largest proportion of af- 
Table 2. Effects of sowing time on plant height of sweet sorghum (cm).

\begin{tabular}{ccccc}
\hline \multirow{2}{*}{ Sowing time } & \multicolumn{3}{c}{ Days aftersowing (d) } & Harvest \\
\cline { 2 - 4 } & 30 & 60 & 90 & $390.5 \mathrm{ab}$ \\
Mar. 25 & $68.8 \mathrm{~cd}$ & $269.7 \mathrm{~b}$ & $390.5 \mathrm{ab}$ & $392.9 \mathrm{ab}$ \\
Apri. 15 & $73.1 \mathrm{bc}$ & $297.7 \mathrm{a}$ & $392.9 \mathrm{ab}$ & $400.3 \mathrm{ab}$ \\
May 15 & $78.8 \mathrm{ab}$ & $288.8 \mathrm{a}$ & $400.3 \mathrm{ab}$ & $409.2 \mathrm{a}$ \\
Jun. 15 & $84.7 \mathrm{a}$ & $301.8 \mathrm{a}$ & $409.2 \mathrm{a}$ & $378.1 \mathrm{~b}$ \\
Jul. 15 & $65.2 \mathrm{~d}$ & $265.9 \mathrm{~b}$ & $378.1 \mathrm{~b}$ & $241.3 \mathrm{c}$ \\
Aug. 15 & $43.3 \mathrm{e}$ & $236.2 \mathrm{c}$ & $241.3 \mathrm{c}$ & $<0.01$ \\
P & $<0.01$ & $<0.01$ & $<0.01$ & \\
\hline
\end{tabular}

Table 3. Effects of sowing time to lodging of sweet sorghum (\%).

\begin{tabular}{ccccccccc}
\hline Sowing times & March & April & May & June & July & August & $P$ & \\
\hline Lodging (\%) & $6.7 \mathrm{c}$ & $15.6 \mathrm{~b}$ & $20.3 \mathrm{a}$ & $16.4 \mathrm{ab}$ & $5.9 \mathrm{c}$ & $3.9 \mathrm{c}$ & $<0.01$ \\
\hline
\end{tabular}

Table 4. Percentage (\%) of affected plants by pests and diseases.

\begin{tabular}{cccc}
\hline Sowing times & Stem borer (\%) & Stem rot by bacteria (\%) & Root rot by fungi (\%) \\
\hline March & $16.6 \mathrm{ab}$ & $17.1 \mathrm{a}$ & $12.7 \mathrm{a}$ \\
April & $20.8 \mathrm{a}$ & $13.5 \mathrm{abc}$ & $10.5 \mathrm{ab}$ \\
May & $14.8 \mathrm{bc}$ & $14.3 \mathrm{ab}$ & $9.6 \mathrm{~b}$ \\
June & $15.8 \mathrm{ab}$ & $11.6 \mathrm{bcd}$ & $9.1 \mathrm{~b}$ \\
July & $10.0 \mathrm{~cd}$ & $8.7 \mathrm{~cd}$ & $8.3 \mathrm{bc}$ \\
August & $7.4 \mathrm{~d}$ & $6.7 \mathrm{~d}$ & $6.3 \mathrm{c}$ \\
$\mathrm{P}$ & $<0.01$ & 0.01 & $<0.01$ \\
\hline
\end{tabular}

fected plants by stem borer was 20.8\% when sorghum was sowed in April, and the lowest harmfulness came to August treatment, with only $7.4 \%$. In other periods, the infected rate were $16.6,15.8 \%$ and $14.8 \%$ of March, June and May, respectively. In July, this ratio reduced twice compared to these periods. Regarding diseases caused by microorganisms in both stem and root of sweet sorghum, it was demonstrated that plants sowed in March and June highly affected with $17.1 \%$ and $12.7 \%$, respectively, and the infection percentage was slightly decreased of approximately 2\% - 3\% in July, April and May. Sowing in August witnessed the lowest disease proportion by microorganisms, which was only 6.3\%. However, these percentages of affected sweet sorghum were still good and slightly good in these periods.

\subsection{Biomass Quality}

Planting should be taken place at a time when the environmental temperature is higher $12^{\circ} \mathrm{C}$, and the later sweet sorghum is sowed, the lower plant biomass and quality, sugar content included would be [12]. The quality parameters of sweet sorghum were showed in Table 5. In overall, in term of sowing times, the plant height, number of leaves, fresh weight and biomass yield had similar trend. They were not significant different in March, April, May and June while plants sowed in July and August significantly decreased biomass and quality. Particularly, the height plant was over $380 \mathrm{~cm}$ sowing in case of from March to June ( $p>0.05)$, meanwhile this figure was $378.1 \mathrm{~cm}$ in July and only $241.3 \mathrm{~cm}$ in August ( $<0.05$ ), respectively. The number of leaves was from 18 to 21 leaves each plant. Similarly plants sowed in July and August had lower difference of leaves in comparison with the other planting times $(\mathrm{p}<0.01)$. Sweet sorghum agronomy largely impacts the biomass yield of plant including fresh weight and sugar content which is mainly produced by carbohydrate in stem via photosynthesis process [12]. The fresh weight of stem and the whole plant of sweet sorghum were definitely higher than other varieties, which had the highest weight in April with $1310.4 \mathrm{~g} / \mathrm{plant}$ and $1084.1 \mathrm{~g} / \mathrm{stem}$, respectively. In the study of Chamarthy et al. [1] the highest yield of fresh weight of the IS 8007 cultivar was 995 g/plant [1], and 
the average weight was only $596 \mathrm{~g} /$ plant. As the result of high fresh weight, the total biomass yield and stem yield were high accordingly, which accounts for 73.7 tons/ha (August) to 122.4 tons/ha (May) in the case of biomass yield and 58.8 tons/ha (August), 91.2 tons/ha (May) regardless of the stem yield. Planting times in March, April, May and June were not significantly different ( $p<0.01)$, but significantly different in July and August. Another important parameter of sweet sorghum quality defined as sugar content is Brix level. Although, the planting time obtained the extremely high yield in plant biomass was observed, the Brix level simply obtained medium level of sweet sorghum, with from $14.2 \%$ to $14.9 \%$ when sowing in March to July ( $p>0.05$ ), $13.6 \%$ in August $(\mathrm{p}<0.05)$. The Brix value of sweet sorghum in India was from $14.9 \%$ to $16.5 \%$ in study of Rao et al. [6], 23\% in the circumstance of Mariano Marcos State University [10], and 19\% in average in the study of Almodarees and Hadi [12]. However, these Brixvalues were also normal in average range of sweet sorghum. Briefly, the planting time from March to June was strongly recommended for obtaining high biomass and sugar content of sweet sorghum in Thai Nguyen.

The primary objective of cultivating sweet sorghum is the biofuel that is converted from the sugar content expressed as ethanol yield [2] [11] [12] [19] [20]. Theoretically, the ethanol productivity was calculated and showed in Figure 2. The ethanol trend was analogous to the sugar change effected by variable planting times. In March, the ethanol yield was nearly 5 tons/ha, and it was insignificantly different from planting in April, May, June and July, although the figures in these periods showed a slight discrepancy $(p>0.05)$. Promisingly, sweet

Table 5. Effects of sowing time on harvest parameters of sweet sorghum (\%).

\begin{tabular}{|c|c|c|c|c|c|c|c|}
\hline Sowing times & $\begin{array}{l}\text { Plant height } \\
\text { (cm) }\end{array}$ & $\begin{array}{l}\text { No. of leaves } \\
\text { (leaves/plant) }\end{array}$ & $\begin{array}{l}\text { Fresh weight } \\
\text { (g/whole plant) }\end{array}$ & $\begin{array}{l}\text { Fresh weight } \\
\text { (g/stem) }\end{array}$ & $\begin{array}{l}\text { Brix } \\
(\%)\end{array}$ & $\begin{array}{l}\text { Biomass yield } \\
\text { (tons/ha) }\end{array}$ & $\begin{array}{l}\text { Stem yield } \\
\text { (tons/ha) }\end{array}$ \\
\hline March & $390.5 \mathrm{ab}$ & $21.2 \mathrm{a}$ & $1231.7 \mathrm{ab}$ & $1020.6 \mathrm{ab}$ & $14.4 \mathrm{a}$ & $115.4 \mathrm{a}$ & $89.2 \mathrm{a}$ \\
\hline April & $392.9 \mathrm{ab}$ & $21.3 \mathrm{a}$ & $1297.4 \mathrm{a}$ & $1063.4 \mathrm{ab}$ & $14.2 \mathrm{a}$ & $112.3 \mathrm{ab}$ & 87.7 a \\
\hline May & $400.3 \mathrm{ab}$ & $21.7 \mathrm{a}$ & $1310.4 \mathrm{a}$ & $1084.1 \mathrm{a}$ & $14.6 \mathrm{a}$ & $122.4 \mathrm{a}$ & $91.2 \mathrm{a}$ \\
\hline June & $409.2 \mathrm{a}$ & $21.1 \mathrm{a}$ & $1270.6 \mathrm{a}$ & $1049.7 \mathrm{ab}$ & 14.9 a & 117.8 a & $89.4 \mathrm{a}$ \\
\hline July & $378.1 \mathrm{~b}$ & 20.9 a & $1148.3 \mathrm{~b}$ & $947.4 \mathrm{~b}$ & $14.8 \mathrm{a}$ & $99.0 \mathrm{~b}$ & $81.2 \mathrm{~b}$ \\
\hline August & $241.3 \mathrm{c}$ & $18.3 \mathrm{~b}$ & 827.5 c & $662.1 \mathrm{c}$ & $13.6 \mathrm{~b}$ & $73.7 \mathrm{c}$ & $58.8 \mathrm{c}$ \\
\hline $\mathrm{P}$ & $<0.01$ & $<0.01$ & $<0.01$ & $<0.01$ & $>0.05$ & $<0.01$ & $<0.01$ \\
\hline
\end{tabular}

Means with different following letters in the same column are significantly different at 95\% confidential level.

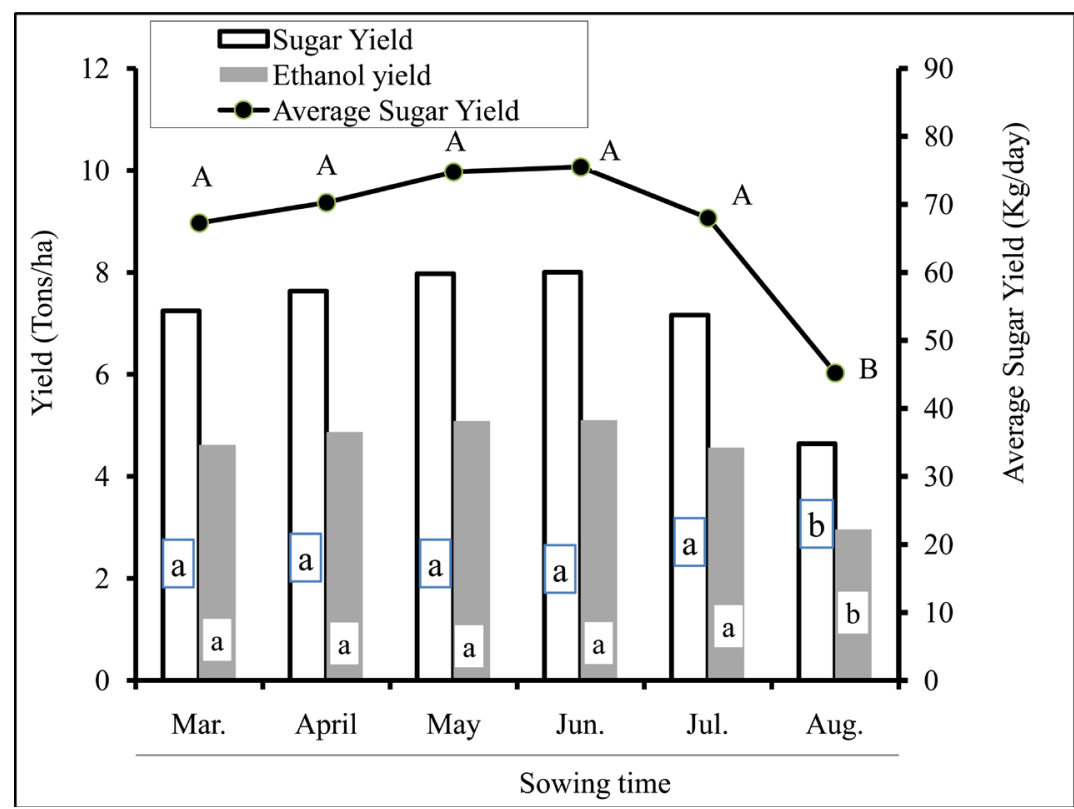

Figure 2. Effect of sowing time on ethanol yield of sweet sorghum, means with different following letters is significantly different at 95\% confidential level. 
sorghum can be planted in Thai Nguyen for bioethanol production because of elevated yield. The sweet sorghum cultivated in semiarid climate only produced from 1 to 1.2 tons/ha with prospective cultivars including SSV84, SSV74, CSV19SS and CSH22SS [6], 1.9 tons/ha in USA [5], or from 2.4 to 3.2 tons/ha in Croatia [3].

\section{Conclusion}

Thai Nguyen was a potential region for cultivating sweet sorghum as a feedstock for bioethanol production. Thanks to their warm temperature, the months from March to June were evaluated to be the most appropriate time for sowing sweet sorghum with an effort of collecting high biomass and ethanol product. Moreover, during these sowing periods, sorghum plants were less likely to be infected by pests, diseases and lodging.

\section{Acknowledgements}

We gratefully thank the Vietnam Ministry of Science and Technology for financial support to carry out this research.

\section{References}

[1] Chamarthy, V., Ratnavathi, S.R.K., Bathula, S., Vijay, K., Dasari, G.K. and Jagannath, V.P. (2012) Effect of Time of Planting on Cane Yield and Quality Characters in Sweet Sorghum. Journal of Sustainable Bioenergy Systems, 2, 1-9. http://dx.doi.org/10.4236/jsbs.2012.21001

[2] Cifuentes, R., Bressani, R. and Rolz, C. (2014) The Potential of Sweet Sorghum as a Source of Ethanol and Protein. Energy for Sustainable Development, 21, 13-19. http://dx.doi.org/10.1016/j.esd.2014.04.002

[3] Dubravko, M. and Zvonimir, S. (2008) Biomass Production and Ethanol Potential from Sweet Sorghum in Croatia. Alps-Adria Scientific Workshop, Stara Lesna, Slovakia, 527-530.

[4] Doran-Peterson, J., Cook, D.M. and Brandon, S.K. (2008) Microbial Conversion of Sugars from Plant Biomass to Lactic Acid or Ethanol. The Plant Journal, 54, 582-592. http://dx.doi.org/10.1111/j.1365-313X.2008.03480.x

[5] Regassa, C.S. (2011) Sweet Sorghum as a Bioenergy Crop for the US Great Plains Economic Effects of Biofuel Production [Internet].

http://www.intechopen.com/books/economic-effects-of-biofuelproduction/sweet-sorghum-as-a-bioenergy-crop-for-theus-great-plains

[6] Rao, S.S., Patil J.V., Prasad, P.V.V., Reddy, D.C.S., Mishra, J.S. and Umakanth, A.V. (2013) Sweet Sorghum Planting Effects on Stalk Yield and Sugar Quality in Semi-Arid Tropical Environment. Agronnomy Journal, 105, 1458-1465. http://dx.doi.org/10.2134/agronj2013.0156

[7] JICA (2009) JICA Supports Vietnam Developing the Sustainable Integration of Local Agriculture and Biomass Industries. Japan International Cooperation Agency, Tokyo.

[8] Vinutha, K.S., Rayaprolu, L., Yadagiri, K., Umakanth, A.V., Patil, J.V. and Srinivasa, R.P. (2014) Sweet Sorghum Research and Development in India: Status and Prospects. Sugar Technology, 16, 133-143.

http://dx.doi.org/10.1007/s12355-014-0302-9

[9] Olsen, M.M. (2009) Growing Grain Sorghum in Arizona. The University of Arizona Cooperative Extension. Maricopa County.

[10] ICRISAT (2007) Sweet Super Sorghum-Yield Data for the ICRISAT Hybrid. BIOPACT: Toward an Green Energy Pact between Europe and Africa [Internet]. http://news.mongabay.com/bioenergy/2007/02/sweet-super-sorghum-yield-data-for.html

[11] Fernandes, G., Braga, T.G., Fischer, J., Parrella, R.A.C., de Resende, M.M. and Cardoso, V.L. (2014) Evaluation of Potential Ethanol Production and Nutrients for Four Varieties of Sweet Sorghum during Maturation. Renewable Energy, 71, 518-524. http://dx.doi.org/10.1016/j.renene.2014.05.033

[12] Hadi, A.A. (2009) Production of Bioethanol from Sweet Sorghum: A review. African Journal of Agricultural Research, 4, 772-780.

[13] Mehmood, S.G., Muhammad, T. and Muhammad, S. (2014) Statistical Screening and Selection of Sweet Sorghum Varieties for Bioethanol Eroduction. Pakistan Journal of Botany, 46, 1115-1120.

[14] Vietnam-Country-and-People. Vietnam Climate 2014. http://www.vietnamtourism.com/e_pages/country/overview.asp?uid=1752

[15] Climate-Data. Climate: Thai Nguyen Climate Data 2014. http://en.climate-data.org/location/4254/

[16] Tian, Y., Guan, B., Zhou, D., Yu, J., Li, G. and Lou, Y. (2014) Responses of Seed Germination, Seedling Growth, and 
Seed Yield Traits to Seed Pretreatment in Maize (Zea mays L.) The Scientific World Journal, 8 p.

[17] Plessis, J. (2008) Sorghum Production. ARC-Grain Crops, Institute. Private Bag X1251, Potchefstroom 2520 [Internet]. http://www.nda.agric.za/docs/Infopaks/FieldCrops_Sorghum.pdf

[18] Chindaruksa, S. and Pin, M. (2008) Bioethanol from Sweet Sorghum-A Review of the Opportunities. Lampi di stampa, Milano, Italy, 126 p. Gorizia.

[19] Bhairappanavar, S. (2011) Bio-Ethanol Production Potential of Sweet Sorghum (Sorghum bicolor) Cultivars under Different Spacing and Harvest Stages. Indian Journal of Agronomy, 56, 52-56.

[20] Davila-Gomez, F.J., Chuck-Hernandez, C., Perez-Carrillo, E., Rooney, W.L. and Serna-Saldivar, S.O. (2011) Evaluation of Bioethanol Production from Five Different Varieties of Sweet and Forage Sorghums (Sorghum bicolor (L.) Moench). Industrial Crops and Products, 33, 611-616. http://dx.doi.org/10.1016/j.indcrop.2010.12.022 